\title{
Medya Sektöründe Marka Mimarisi: Netflix Örneği
}

\section{Onur TÜRKER ${ }^{1}$, Parisa ALİZADEHFANAELOO² ve Hacer Handan DEMİR ${ }^{3}$ \\ Öz}

Markanın stratejik olarak ne konumda olduğunu gösteren marka mimarisiyle ilgili yazında yapılmış çalışmalar perakendeci markalar, tüketici ürünü markaları, hizmet markaları, endüstriyel ürün markaları, ülke ve şehir markaları üzerine yoğunlaşmışır. Ayrıca yazında spor markaları, sanat markaları, politika markaları, eğitim markaları, ilaç markası ve uluslararası alanda faaliyet gösteren markalara ilişkin de marka mimarisi çalışmaları bulunmaktadır. Bu çalışmanın amacı, Netflix ana markası ve Netflix’te yayınlanan diziler yani alt markaları arasında marka mimarisi Özellikleri açısından farklılıkları ortaya koymaktır. Çalışmada İstanbul ilinde Netflix ve yayınlarını izleyen 300 kişiye anket uygulanmıştır. Araştırma sonucunda Netflix ve alt markaları arasında marka mimarisi özellikleri açısından ve ayrıca cinsiyet arasında farklılıkların nasıl bir şekilde olduğu tespit edilmiştir.

Anabtar Kelimeler: Marka Mimarisi, Netflix, Cezbedicilik. Merkezilik, Kendini İfade

\section{Brand Architecture in Media Sector: The Case of Netflix}

\section{Abstract}

In this study, it was identified the strategic position of brand pertaining brand architecture focused on studies about retailer brands, consumer product brands, service brands, industrial product brands, country and city brands. Furthermore, there are studies in sport brands, art brands, policy brands, educational brands, drug brands and brands actuate in international area context in brand architecture. The purpose of this study is to designate differences between Netflix as major brand and series as sub-brands published in Netflix, in terms of brand architecture characteristics. In related study, in Istanbul 300 people who follow Netflix and it's publications completed the questionnaires. As a result of research, it is adjusted that in terms of brand architecture features how there is a difference between Netflix and its series, differences between gender groups and between professional groups as well.

Key Words: Brand architecture, Netflix, Attractiveness. Centralization, Self-expression

\section{Atıf İçin / Please Cite As:}

Türker, O., Alizadehfanaeloo, P. ve Demir, H. H. (2021). Medya sektöründe marka mimarisi: Netflix örneği. Manas Sosyal Arașturmalar Dergisi, 10(2), 1264-1280.

Geliş Tarihi / Received Date: 24.12.2020

Kabul Tarihi / Accepted Date: 05.03.2021

\footnotetext{
${ }^{1}$ Arş. Görevlisi - Türkiye -İstanbul Gelişim Üniversitesi Uygulamalı Bilimler Yüksekokulu, oturker@gelisim.edu.tr

(iD ORCID: 0000-0002-5119-0313

2 Dr. Öğr. Üyesi. - Türkiye-İstanbul Gelişim Üniversitesi Uygulamalı Bilimler Yüksekokulu, palizadehfanaeloo@gelisim.edu.tr

(i) ORCID: 0000-0001-9972-6079

3 Dr. Öğr. Üyesi - Türkiye-İstanbul Gelişim Üniversitesi Uygulamalı Bilimler Yüksekokulu, hhdemir@gelisim.edu.tr

(iD) ORCID: 0000-0001-6157-9181
} 


\section{Giriş}

İşletmeler kendi ürünlerinin kaynağını tanımlamak ve rakiplerinden ayırt edilmesini sağlamak amacıyla isim, sembol vb. pek çok öğeyi bir araya getirerek markayı oluşturmaktadır. Marka ve ürün arasındaki ilişkileri düzenleyen sistem marka mimarisi olarak adlandırılmaktadır (Kapfarer, 2004, s. 310). Marka mimarisi kavramıla yazında eş değer olarak kullanılan ifadeler marka hiyerarşisi, marka portföyü ve marka stratejileri şeklindedir.

Marka mimarisi kavramı pazarlamacılar için oldukça önemli olmaktadır. Marka mimarisi pazarlamacılara marka adlarını, logolarını, sembolleri ve markayla ilişkili diğer öğeleri mevcut ve yeni ürünlere ne şekilde uygulanacağıyla ilişkili yol göstermektedir (Keller, 2014, s. 703). Marka mimarisiyle markalar pazar firsatlarını, bölümlerini, sunduğu ürünlerin özelliklerini psikolojik olarak birbiriyle bağlamayı hedeflemektedir (Uglla ve Philipsonn, 2009, s. 19). Marka mimarisiyle markalar, marka sistemi içerisinde hiyerarşik olarak yerleştirilmektedir. Bu şekilde sinerji yaratılarak ortak kullanımdan yararlanılmakta, marka kimliği hasarı azaltılmakta, marka ile ilgili müşterilere daha net teklifler verilmekte ve değişim kolaylaşmaktadır. Marka mimarisinde hiyerarşik olarak yerleştirilmiş olan her markanın kendine özgü bir rolü olmakta ve diğer seviyedeki markalarla bu roller ilişkili olmaktadır (Aaker ve Joachimsthaler, 2000, s. 282).

Marka mimarisiyle ilgili çalışma eksikliği bulunan en önemli alanlardan birisi medya markaları olmaktadır. Dünyada ve Türkiye'de hiçbir alanda medya markalarına yönelik olarak yapılmıs marka mimarisi çalışması bulunmamaktadır. Özellikle internetin gelişmesiyle ortaya çıkan medya markaları olan dijital yayın platformlarına yönelik bir marka mimarisi çalışması yapmanın diğer alanlarda da yapılan medya markalarına yönelik çalışmalara referans oluşturacağı öngörülmektedir. Araştırmanın konusunu dijital yayın platformu alanındaki medya markalarının marka mimarisini nasıl şekillendirdiğini ve tüketiciler tarafından marka mimarisi stratejisinin nasıl algılandığını belirlemek oluşturmaktadır. Bu çalışma medya sektöründe marka mimarisinin nasıl şekillendirilmesi gerektiğini ortaya koyarak yazındaki önemli bir eksikliği gidermektedir.

\section{Literatür Taramas1}

\section{Marka Mimarisi Kavramı}

Marka mimarisi, marka rollerini ve markaların arasındaki ilişkilerin doğasını belirleyen marka portföyünün organize bir yapısı olarak tanımlanmaktadır. Marka mimarisi, işletmelere markalarının stratejik olarak hangi konumda olduğunu göstermesi konusunda yardımcı olmaktadır (Aaker ve Joachimsthaler, 2000, s. 280). Yazında marka mimarisi ile ilgili birçok önemli sınıflandırma bulunmaktadır. Bu sınıflandırmalardan birincisi Kapfarer tarafindan gerçekleştirilen altılı bir sınıflandırmadır (Kapferer, 2004, s.316-326):

1. Ürün- Marka Stratejisi: Yapılan konumlandırmaya uygun olarak bir ürüne veya ürün hattına bir marka ismi vermektir. Örneğin Protect\& Gamble'ın birbirinden farklı çözümler üreten deterjanlarına farklı markalar vermesi gibi ürün marka stratejisi çerçevesinde ürün markaları bulunmaktadır. Deterjan sektörü göz önüne alındığında P\&G’nin Ariel, Vizir, Dash, Camay vb. birbirinden farklı ihtiyaçları karşılayan markaları bulunmaktadır. Örneğin, Ariel uygun fiyatlarıyla ön plana çıkmaktayken, Camay hoş sabun kokusuyla ön plana çıkmaktadır.

2. Hat- Marka Stratejisi: Belli bir hatta bulunan, birbirini tamamlayan veya ilişkili olan ürünlere aynı marka ismini vermektir. Calgon markasının sunduğu çamaşır makinesi kireç önleyicileri, deterjanları, bulaşık makinesi temizleme tozları hat marka stratejisine önemli bir örnek olmaktadır. Hat-marka stratejisinin avantajı belli bir yöne odaklanarak faaliyetlerde verimlilik yakalanmasıdır. Hat marka stratejisinin dezavantajı ise, belirlenen standartların dışında (farklı hatlarda) ürün sunamamasıdır.

3. Menzil (Alan) Marka Stratejisi: Tek bir marka ve tek bir slogan kullanarak aynı alana yönelik faaliyette bulunmaktır. Bu marka türü kozmetik, gıda, aksesuar ve sanayi ürünlerinde yaygın olarak kullanılmaktadır. Örneğin, Clarins markası sunduğu nemlendirici ürünlerle menzil marka stratejisi uygulayan bir marka olmaktadır. Bu stratejinin dezavantajı farklı ürün kategorilerine girmekte zorlanmaktır.

4. Şemsiye Marka Stratejisi: Farklı ürünler için ortak bir marka adı kullanmaktır. Örneğin, Canon markası adı altında fotoğraf makineleri, yazıcılar, faks makineleri vb. farklı ürünler bulunmaktadır. $\mathrm{Bu}$ marka stratejisi daha çok yeni pazarlara girerken uygulanmaktadır. 
5. Kaynak Marka Stratejisi: Bir kaynak marka adı ve buna bağlı olarak farklı ürün marka adları kullanmaktır. İki katmanlı bir marka yapısı olmaktadır. Kaynak markaya bağlı her ürün markasının farklı şekilde kendini ifade edişi bulunmaktadır. Kaynak marka stratejisinde, kaynak marka, ürün markasından daha önemli olmaktadır.

6. Onaylı Marka Stratejisi: Ürün, hat, menzil vb. bütün markalara onay verme yetkisine sahip olan tek bir marka olmaktadır. Bu stratejiye göre onay markaları ikincil pozisyonda bulunmakta ve diğer marka türlerinin yanında ön plana çıkmamaktadır. Örneğin, GM Buick, Cadillac ve Chevrolet gibi otomobil markalarının onay markası durumundadır.

\begin{tabular}{|c|c|c|c|c|c|c|c|c|}
\hline \multicolumn{3}{|c|}{ Ürün Markaları } & \multicolumn{3}{|c|}{ Şemsiye Markalar } & \multicolumn{3}{|c|}{ Hat Marklar1 } \\
\hline & & & \multicolumn{3}{|c|}{ Marka ya da kurum } & & & \\
\hline & & & & & & \multicolumn{3}{|c|}{ Ürün Ya da Kurum } \\
\hline \multirow{2}{*}{$\begin{array}{l}\text { Marka } \\
\text { A }\end{array}$} & & & & & & & $\downarrow$ & \\
\hline & $\begin{array}{l}\text { Marka } \\
\text { B }\end{array}$ & $\begin{array}{l}\text { Marka } \\
\text { C }\end{array}$ & Urün & Urün & Urün & Ürün & Ürün & Pürün \\
\hline \multicolumn{9}{|c|}{ (Gizli Kurumsal) } \\
\hline \multicolumn{3}{|c|}{$P \& G$} & \multicolumn{3}{|c|}{$\begin{array}{l}\text { Mitsubishi, } \\
\text { Samsung }\end{array}$} & \multicolumn{3}{|c|}{ Nivea/Sony } \\
\hline \multicolumn{3}{|c|}{ Üretici Markaları } & \multicolumn{3}{|c|}{ Onaylanmış Markalar } & \multicolumn{3}{|c|}{ Kaynak Markalar } \\
\hline \multirow{2}{*}{\multicolumn{3}{|c|}{ Kurumsal ad }} & \multirow{2}{*}{\multicolumn{2}{|c|}{$\begin{array}{l}\text { Marka A } \\
\text { Kurum }\end{array}$}} & MarkaB & \multicolumn{3}{|c|}{ Marka ya da Kurum } \\
\hline & & & & & Kurum & $\downarrow$ & 1 & 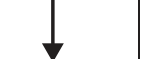 \\
\hline \multicolumn{3}{|c|}{ Marka A } & & & & $\begin{array}{c}\text { Alt Marka } \\
\text { A }\end{array}$ & $\begin{array}{c}\text { Alt Marka } \\
\text { B }\end{array}$ & $\begin{array}{l}\text { Alt Markad } \\
\mathrm{C}\end{array}$ \\
\hline & Ferrero & & & $\overrightarrow{3 M}$ & & \multicolumn{3}{|c|}{ l'Oréal Paris } \\
\hline
\end{tabular}

Şekil 1. Kapferer Marka Mimarisi (Kapferer (2004, s. 316)

İkinci sınıflandırma Aaker ve Joachimsthaler (2000, s. 287-295) tarafindan gerçekleștirilen marka ilişkileri spectrumu olarak bilinen dörtlü bir sınıflandırmadır:

Markaların Evi: Her ürün kategorisi veya kanalı için ayrı bir marka oluşturulmuştur. $\mathrm{Bu}$ ayrı markaların her biri kendilerinden sorumlu olmakta ve bağımsız hareket etmektedir. Bir markanın başarısı veya başarısızlığı diğer hiçbir markasını etkilememektedir. Markaların evi stratejisinin en önemli örneği $P \& G$ olmaktadır. P\&G şirketinin birbirinden tamamen bağımsız 80 tane markası bulunmaktadır. Örneğin saç bakım markası olarak Pantene, Head \& Shoulders, Rejoice gibi farklı markları bulunmaktadır.

Onaylanmış Markalar: Burada ürün markaları ön planda olmakla birlikte, onları onaylayan temel bir marka bulunmaktadır. Ana marka tarafından verilen onay alt markanın güvenilirliği arttırmaktadır. Örneğin, dünyaca ünlü Country Yard Otellerinin onaylayıcı markası Marriot olmaktadır. CountryYard Marriot Otellerinin ismini kullanarak tüketicilerine kaliteli ve güvenli bir marka olduğunu göstermektedir.

Alt markalar: Burada, ana marka ile ürün markası arasındaki ilișki çok daha güçlü olmaktadır. Ana marka daha önemli olmasına karşın, alt marka imajı güçlendirici bir niteliğe sahip olmaktadır. Ana marka pilotken, alt marka yardımcı pilot niteliğinde olmaktadır. Örneğin, Gillete Mach3 markası buna örnek oluşturmaktadır. Her iki markanın da birbirine üstünlüğü bulunmamaktadır. Mach 3 markası ürün olarak başarılı bir tıraş makinesidir. Gillete gibi tıraş makineleriyle ünlü bir markanın ismiyle özelliğini güçlendirmektedir (Aaker ve Joachimsthailer, 2000, s. 14).

Markalı Ev: Burada ana marka baskın bir rol üstlenirken, alt markalar sadece tanımlayıcı nitelikte yer almaktadır. Bu stratejide şirket markasına odaklanılmaktadır. Şemsiye şekilde ürünleri içine alan bir stratejidir. Örneğin, Virgin markası bu duruma örnek oluşturmaktadır. Virgin Hava Yolları, Virgin Express, Virgin Rail, Virgin Radio vb. Virgin markasına aittir. Markalı ev stratejisine göre bir markanın yarattı̆̆1 marka değeri diğer markaları da etkilemektedir (Aaker ve Joachimsthailer, 2000, s. 295). 
Keller markaların mimarisini bir hiyerarşi içerisinde açıklamaya çalışmaktadır. Bu hiyerarşi içerisinde seviyeler aşağıdaki gibidir (Keller, 2008, s. 370).

Kurumsal Marka Seviyesi: Hiçbir alt marka bulunmayıp, şirketin isminin ön planda olduğu seviyedir. Örneğin, General Motors ve Hawlet- Packard işletmeleri marka adı olarak şirket isimlerini kullanmaktadır.

Aile Marka Seviyesi: Kurum markasına bağlı olan farklı kategorilere ait alt markaların bulunduğu seviyedir. Örneğin Pepsi Co markasının, Fritol-ay ve Quaker Foods vb. alt markaları bulunmaktadır.

Bireysel Marka Seviyesi: Bu seviyede bir ürün kategorisine yönelik markalar bulunmaktadır. Örneğin Frito-lay cips markasının Doritos, Ruffles, Lays vb. farlı markaları bulunmaktadır.

Değiştirici Seviyesi: $\mathrm{Bu}$ seviyede bir markanın özelliklerine uygun olarak yeni markalar geliştirilmektedir. Örneğin, Doritos’un peynirli, biberli farklı lezzetlerde ürün sunmasıdır.

Ürün Tanımlama Seviyesi: Tüketiciye ürünün fonksiyonlarılla ilgili verilecek bilgilerin yer aldığ1 seviyedir. Örneğin bir kütüphane markası topluma hizmet rolünü vurgulamaktadır.

Muzellec ve Lamkin marka mimarisi stratejilerini üç şekilde sınıflandırmıştır. Bu sınıflandırmalar aşağıdaki şekilde yer almaktadır (Muzellec ve Lambkin, 2009, s. 47-50).

Kurumsal Ticari İsim: Kurumsal ticari isim, kurumsal markanın aktif olarak tanıtılmadığı, ancak bağımsız markaların bir koleksiyonunu barındıran basit bir şemsiye isimdir. En önemli örnekleri, P\&G, Teyco ve Unilever markaları olmaktadır. Kurumsal isimler yoluyla işletmeler dürüstlük, liderlik, sahip olma, kazanma ve güvene yönelik tutku vb. değerleri tüketicilere gösterirken, bu değerlerin tanıtımını ticari markalarıyla yapmamaktadır. Tüketiciler markaların kurumsal isimlerinin farkında olmalarına rağmen, kurumsal isme sahip markaları herhangi bir ürünle bağdaştıramamaktadır.

Hükümet
ve diğer
kurumlar
Medya
Genel
toplum

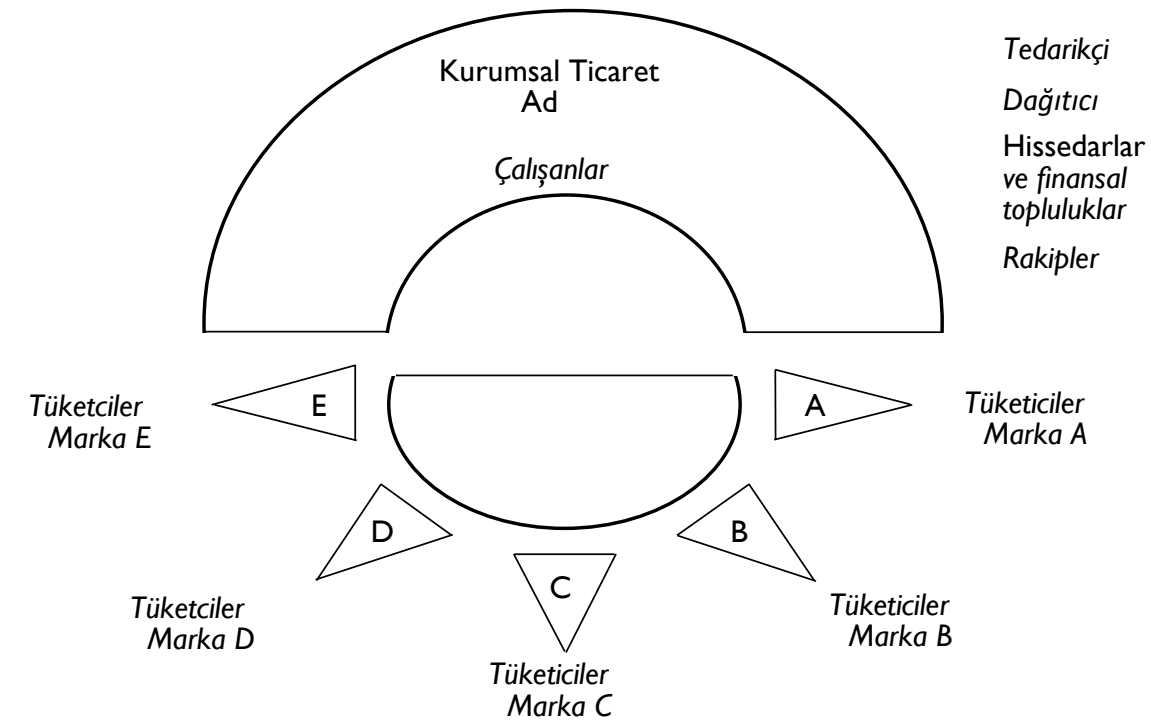

Şekil 2. Kurumsal Ticari İsim (Muzellec ve Lambkin (2009, s. 47)

İşletme Markası: İşletme markası, tüketicilerden çok işletmeyi paydaşlarına tanıtmak için kullanılan işletmenin kurumsal ismi olmaktadır. Tüketicilerin işletme markasını fark edebilmeleri için ürün ambalajlarının üzerindeki küçük yazıları dikkatli okumaları gerekmektedir. En önemli örnekleri 3M, Heinz ve Diageo markaları olmaktadır. Kurumsal markalama her zaman için tek bir monolitik yapı olmamakta, aynı zamanda birçok paydaş grubunun her biri için ayrı ayrı yapılandırılabilen çok boyutlu bir yap1 olabilmektedir. Örneğin, Smirnoff markası tüketicilere yönelik bir marka olmaktayken, bu markanın ana markası olan Diageo markası ise paydaşlara yönelik bir marka olmaktadır. İşletme Smirnoff markasıyla tüketiciler için havalı, arsız bir marka imajı çizmek isterken, Diageo markası ile ise paydaşlara yönelik olarak finansal olarak güçlü bir marka imaj1 çizmektedir. 


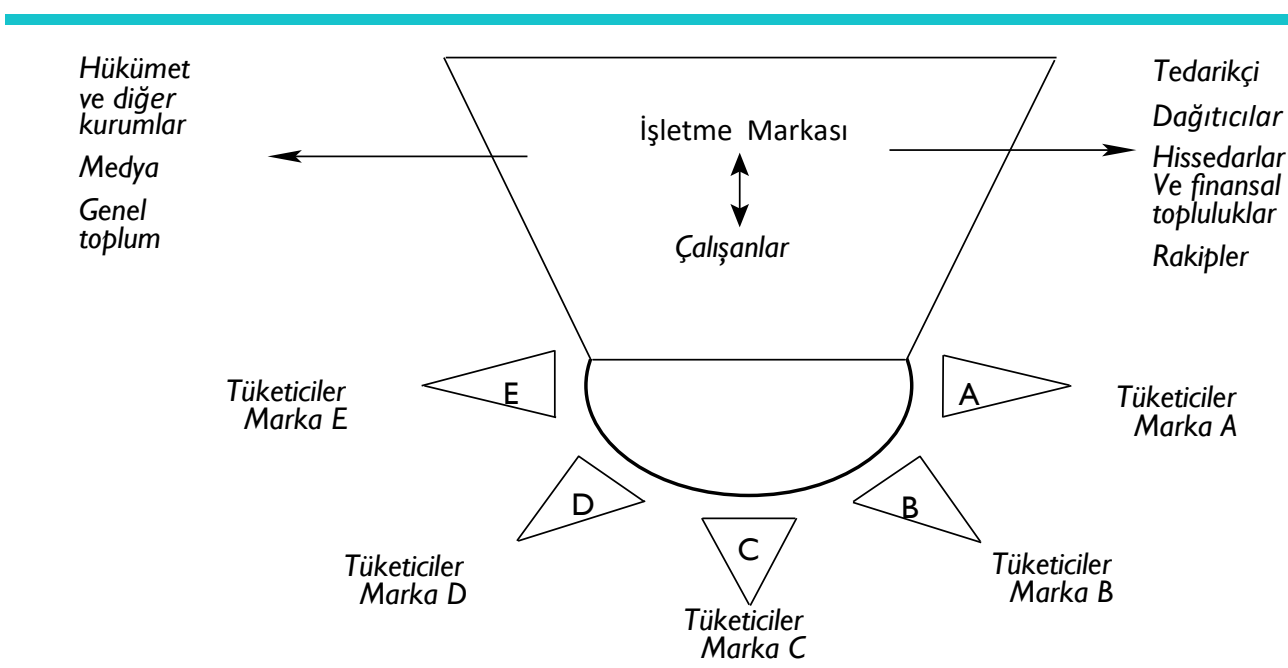

Şekil 3. Işletme Markası (Muzellec ve Lambkin (2009, s. 47)

Holistik Kurumsal Marka: Holistik kurumsal marka, şirketin ve ürünlerin aynı ismi paylaştı̆̆1 bütünsel marka olmaktadır. Bu stratejiyi uygulayan en önemli markalar arasında Accenture, HSBC, Lego, Volvo, Virgin, Air France vb. markalar yer almaktadır. Burada oluşturulan marka hem tüketicilere yönelik olmakta hem de paydaşlara yönelik olmaktadır. Tüketiciler burada ürün markası ve şirket markası arasında herhangi bir ayrım yapamamaktadır. Bu stratejiyle işletmeler marka imajlarıyla yüksek düzeyde bir tutarlılık elde etmek istemektedir.

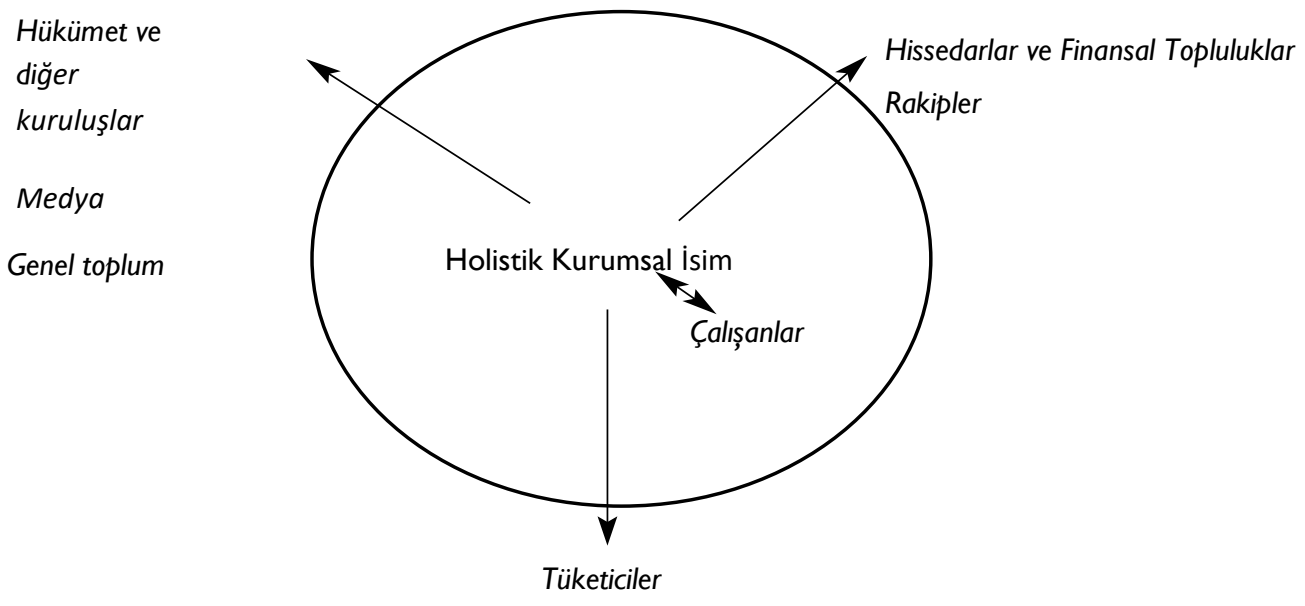

Şekil 4. Holistik. Kurum Marka (Muzellec ve Lambkin (2009, s. 47)

Kapferer kendi marka mimarisi modeline yönelik olarak marka mimarisinin belirleyicilerinin aşağıdaki unsurlar olduğunu söylemektedir (Kapferer, 2004, s. 330-334):

Kurumsal Strateji: Şirketlerin kendi sahip oldukları konumlandırma, rekabet vb. stratejiler marka stratejilerinin farklılaşmasına neden olmaktadır.

İş Modeli: Aynı pazarda bulunmasına rağmen iş modellerinde, yani iş yapış biçimlerindeki farklııı, işletmelerin marka stratejilerinin de farklı olmasına neden olmaktadır.

Kültür: Bir işletmenin içerisinde bulunduğu kültür o işletmenin marka stratejisini etkileyebilmektedir. Örneğin, P\&G Amerika'da ürün marka stratejisiyle yer alırken, Avrupa'da şemsiye marka stratejisi kullanabilmektedir.

İnovasyon Hızı: Teknolojinin sürekli gelişmesi marka stratejilerinin değişmesine neden olmaktadır.

Katma Değerli Kol: Şemsiye marka stratejisi yarattı̆̆1 katma değer ile güvence ve itibarı artıracağından en uygun marka strateji olarak kullanabilmektedir.

Kaynaklar: İşletmenin sahip olduğu finansal kaynakların durumu seçilecek marka stratejisinde etkili olmaktadır.

Marka Vizyonu: Şirketlerin koydukları vizyon seçilecek marka stratejisini etkilemektedir. 
Yönetim Yapıları: İçinde bulunulan yönetim yapısı seçilecek stratejiyi etkilemektedir. Merkezi bir yönetimi bulunmayan işletmeler çok sayıda marka kullanmayı tercih etmektedir.

Rajogopal ve Sanchez'e göre (2004, s. 244) spectrum marka mimarisini belirleyen unsurlar şunlar olmaktadır:

İşletmenin tarihi: İşletmenin gelişim süreci stratejinin belirlemesinde etkili olmaktadır.

Organizasyon Yapısı: İşletmenin organizasyon yapısı marka mimarisi için şablon oluşturmaktadır. etkilidir.

Genişleme Strateji: Birleşme, satın alma vb. genişleme faaliyetleri seçilecek stratejiyi belirlemekte

Ürün Çeşitliliğii: İşletmenin sunduğu ürünlerin miktarı ve türü seçilecek stratejide etkili olmaktadır.

Ürün Pazarı Özellikleri: İçinde bulunulan pazarın homojen mi, değişken mi olduğu strateji seçiminde önemli olmaktadır.

Marka mimarisiyle ilgili yazında yapılmış pek çok sektöre yönelik çalışma bulunmaktadır. Perakendeci mağazalarda yapılan çalışmalarda marka mimarisinin üç boyutu bulunmaktadır. İlk boyut markanın stratejisi olmaktadır. Perakendeci mağazalarda bu stratejiler üretici marka adı ve perakendeci marka adı olmak üzere ikiye ayrılmaktadır. Perakendeci mağazalarda marka mimarisine etki eden ikinci boyut sunulan markaların kalitesi olmaktadır. Üçüncü boyut ise markaların mağaza içerisinde görünürlüğü olmaktadır (Krunert vd., 2006, s. 597). Etkili bir mağaza atmosferi tüketicilerin ürün ve hizmet satın almasını kolaylaştırmaktadır. Bu yüzden perakende marka mimarisinin inşasında işletmeler tüketicilere rol vermelidir. Stratejisi ne olursa olsun markaların mağaza içerisinde ne konumda bulunacağ1 tüketici kararlarını etkilemektedir (Esbjerg ve Larsen, 2003, s. 421). Markaların görülmesini sağlamada mağaza içi düzen önemli olmaktadır. İşletmeler marka mimarisi tasarlarken satış yapılan mağazadaki görünürlügünü dikkate alarak stratejisini belirlemelidir (Kirby ve Kent, 2010, s. 432). Perakendeci mağazalarda marka mimarisi için marka bilinirliliği de önemli olmaktadır. Perakendeciler kurumsal markaları sunmayı daha çok tercih ederken alt markaları daha az sunmaktadır (Simmons vd., 2000, s. 217).

Perakendeci işletmeler dışında üretici konumda bulunan işletmelerde de marka mimarisini doğru belirlemek önemli olmaktadır. Dünyanın en önemli sigara markalarından biri olan Marlboro 2000’li yıllara kadar sadece kendi kurumsal ismiyle markalı ev stratejisi uygulamıştır. 2000’li yıllardan sonra ise Marlboro tüketicilerin farklı istekleri olduğunu fark etmesi sonucunda alt markalar ortaya çıkarmaya başlamıştır (Dewhirst, 2018, s. 241). Dünyada en iyi marka mimarisine sahip olan tüketim ürünleri üreticisi markalarından biri kozmetik ve güzellik ürünleri markası olan Loreal'dır. Loreal'ın marka mimarisi Kapfarer'in modelinde tanımlanan şemsiye marka stratejisidir. Loreal'ın şemsiye markası altında beş ürün bölümü bulunmaktadır. Birinci ürün bölümü olan müşteri ürün bölümünde Loreal Paris, Garnier, Maybelinne NewYork vb. gibi standart geliri olan tüketicilere yönelik markalar bulunmaktadır. İkinci ürün bölümü olan lüks ürün bölümünde Lancome, Biotherm, Helena Rubinstein vb. gibi daha işlevsel ve yüksek gelirli, tüketicilere yönelik markalar bulunmaktadır. Üçüncü ürün bölümü olan profesyonel ürün bölümünde Loreal Professionel, Keresterane, Mizani vb. gibi profesyonel saç bakım uzmanları ve kuaförlere yönelik markalar bulunmaktadır. Dördüncü ürün bölümü olan aktif kozmetik bölümde Vichy, La Roche Possay, Skin Cetuals vb. gibi uzmanlar tarafindan kanıtlanmış, yüksek güvenilirliğe sahip ürünler bulunmaktadır. Markanın beşinci ürün bölümü ise Body Shop adını verdiği güzellik merkezleri olmaktadır (Harish, 2008, s. 43). Loreal markasının şemsiye marka stratejisinde başarılı olmasının temel sebebi sınırlı bir ürün yelpazesine sahip olmasından dolayıdır. Loreal bu stratejiyle maliyetlerini dengede tutmayı başarmıştır. P\&G ve Unilever şirketleri için şemsiye marka stratejisi, bu markaların birbirinden çok farklı ürün yelpazesine sahip olmasından dolayı çok daha zor olmaktadır. Marka mimarisi, şirketin genel kurumsal ve pazarlama stratejileriyle de uyumlu olmaktadır (Harish, 2008, s.50). Ürün işletmeleri gibi tüketicilere hizmet sağlayan işletmeler için de marka mimarisini doğru belirlemek önemli olmaktadır. Hizmet markalarının başarısındaki en önemli faktörlerden birisi alt markalar olmaktadır. Örneğin, Avustralya'da NRMA adlı sigorta markasının tüketicilerine yönelik olarak uyguladığı bir çalısmada, tüketicilerin ana markanın alt markalarından etkilendiği sonucu ortaya çıkmıştır (Rahman ve Areni, 2014, s.339).

Endüstriyel işletmeler kendi kararlarıla yeni markalar oluşturdukları gibi birleşme ve satın alma vb. bütünleşme yollarıly yeni markalar edinebilmektedir. Tüketicilere ürün ve hizmet sunan işletmeler gibi, endüstriyel işletmeler de aynı sektörde olsalar bile farklı marka mimarilerine sahip olmaktadır (Laforet ve 
Saunders, 2005, s. 315). Örneğin, şekerleme endüstrisinde Cadbury, Nestle ve Mars markaları endüstriyel müşterilerine karşı birbirinden oldukça farklı marka stratejilerine sahip olmaktadır. Cadbury markası hem işletmenin adının hem de ürünün adının eşit derecede önemli olduğu karma (çiftli) bir marka stratejisini kullanırken, Nestle markası şirketin isminin daha ön planda olduğu kurumsal baskın marka stratejisini kullanmaktadır. Mars markası ise, şirketin hiç ya da çok az ön planda olduğu daha çok ürün markalarının ön planda olduğu ürün baskın marka stratejisini tercih etmektedir (Saunders ve Fu, 1997, s. 46).

Ülkeler için turist çekme potansiyeline sahip olan şehirler ve bölgeler önemli olmaktadır. Ülkelerin ve şehirlerin önemli yerlerine yönelik olarak yapılan başarılı marka mimarisi tasarımları turizm faaliyetlerinin etkinliğinin artmasına neden olmaktadır (Freire, 2016, s. 79). Ülke marka mimarisini etkileyen dört temel unsur bulunmaktadır. İlk unsur dış alg1 unsurları olmaktadır. Ülke ve şehirler hakkında tüketicilerin sahip olduğu bilgi eksikliği giderilerek ve hedef kitleye doğru bir şekilde ulaşılarak marka algiları mümkün olduğunca olumlu hale getirilmektedir. Ülke marka mimarisini etkileyen ikinci unsur yakınlık durumudur. Ülkeler kendilerine yakın olan diğer ülkelere yönelik olarak ana marka ismini kullanmaktadır. Yakın ülkelerdeki tüketiciler diğer ülkenin özelliklerini bildikleri için ana marka bu ülkeler için yeterli olmaktadır. Örneğin, Hollanda kendi ülkesinin ismini ana marka olarak kullanarak komşu ülkelerdeki turistleri kendisine çekmeye çalışmaktadır. Daha uzaktaki tüketiciler için ise ülkeler kendi ülkesinde önemli, bilinen bir yeri alt marka olarak kullanarak bu ülke vatandaşlarını kendine çekmeye çalışmaktadır. Örneğin, Hollanda uluslararası düzeyde çok bilinen Amsterdam şehrindeki Mademe Tussauds Müzesini alt marka olarak kullanmaktadır. Ülke marka mimarisini etkileyen üçüncü önemli unsur marka ilişkileri olmaktayken, dördüncü önemli unsur politika ve güç olmaktadır. Bir ülkenin kendi bölgesel markalarını doğru tanımlanmış olması gerekmektedir. Yani bir ülkenin ana markasını destekleyecek nitelikteki alt markalarılyla doğru ilişki kurması ve ana markanın tamamlayıcısı olması önemli olmaktadır. Politik durum da ülkelerin marka mimarisini etkilemektedir. Hükümetler kendileriyle zıt düşüncede olan belediye başkanlarına sahip olan bölgeleri değerli olsalar bile alt markası olarak göstermemektedir (Dinnie, 2018, s. 31).

Spor organizasyonlarında takımlar ve bu takımların bağlı olduğu ligler bulunmaktadır. Spor organizasyonların marka mimarisi açısından ligler ana marka olarak kabul edilirken, takımlar ise alt marka olarak kabul edilmektedir. Spor organizasyonlarında takımlar ve bu takımların bağlı olduğu ligler bulunmaktadır. Spor organizasyonların marka mimarisi açısından ligler ana marka olarak kabul edilirken, takımlar ise alt marka olarak kabul edilmektedir. Lig markalarının kalitesi bir ülkenin takımlarının kalitesi hakkında tüketicilere bilgi vermektedir. Örneğin, en üst ligde bulunan takımları tüketiciler tarafindan en güçlü takımlar olarak algılamaktadır. Uluslararası düzeyde bakıldığında alt marka olan takımların kalitesi, ana markası olan liglere olan ilgiyi artırmaktadır. Örneğin, Bayern Münich, Manchester United vb. futbol takımlarının tüketicileri tarafindan güçlü olarak algılanması bu ülkelerin liglerine olan ilgiyi arttırmakta ve talep görmesine neden olmaktadır. (Kunkel, Funk ve Hill, 2013, s. 180).

Marka mimarisi politika alanında geçerli bir kavram olmaktadır. Siyasi partilerin her biri bir ana marka iken bu partilerin adayları ve vaatleri ise alt marka olmaktadır. Siyasi partiler adaylar ve politikaları kullanarak müşterisi olan seçmeni etkilemek istemektedir (Mensah, 2016, s. 70). İlaç markalarının marka mimarisi stratejileri birbirinden farklı olmaktadır. Daha küçük, belli bir tedavi alanında ilaç üretimi yapan şirketler kurumsal bask1 stratejisini uygulamaktadır (Kanits ve Burman, 2012, s. 571). Spry vd.'de (2018) yaptıkları araştırmada üniversitelerin marka mimarilerini nasıl geliştirdiklerini açıklamaya çalışmışır. Öncelikle ana markanın üniversitenin kurumsal adı, alt markaların ise fakülteler ve onlara bağlı programlar olduğu tespit edilmiştir. Marka mimarisinin başlıca üç özelliği bulunmaktadır (Beaton vd., 2011, s. 131):

Cezbedicilik Özelliği: Markaların tüketiciyle etkileşimi sonucu tüketicinin markaya eğilim göstermesiyle ortaya çıkmaktadır. Markalar ana marka veya alt markalar yoluyla tüketiciyle sıkı iletişime geçerek onların gözünde cazip bir konuma ulaşmayı hedeflemektedir.

Merkezilik Özelliği: Markaların tüketiciyle kurduğu duygusal ve fonksiyonel bağ sonucunda markanın tüketicinin gözünde önemli bir yere gelmesiyle ortaya çıkmaktadır. Markalar ana markalar veya alt markalar yoluyla tüketiciyle bağ kurarak onların gözünde önemli bir noktaya ulaşmak istemektedir.

Kendini İfade Özelliği: Markaların tüketicilerin kişiliklerini yansıtan davranış sergilemeleri sonucu tüketicinin markanın kendisini ifade eden bir temsilci gibi görmesiyle ortaya çıkmaktadır. Markalar ana markalar veya alt markalarıyla tüketicilerin kişiliklerini yansıtan bir duruma ulaşmayı hedeflemektedir. 


\section{Netflix Markas1}

Netflix kurumsal markası 1997 yılında Reed Hasting ve Marc Randolph tarafından internet üzerinden film kiralama hizmeti sunmak için kurulmuştur. 2000 marka şirket kullanıcıların özelliklerine dayanarak kişiselleştirilmiş film teklifleriyle önemli bir yeniliğe imza atmıştır. 2007 yllında marka tamamen kendisi tarafindan üretilen film ve diziler çekmeye başlamıştır. Netflix kendi içeriklerini yayınlama atılımıyla birlikte dünya genelinde popülerlik kazanmış ve hızlıca farklı ülkelere yayılmıştır. 2016 yllıyla birlikte tüm dünyada yayınlanan bir dijital medya platformu olmaktadır (Netflix Company Analysıs, 2019, s. 4). Netflix dijital medya platformu markası beş ürün hattına sahiptir. Netflix ana markasının ürün hatlarından ilki Netflix dizileri olmaktadır. Netflix medya merkezine göre ortalama bir Netflix dizisi izleyen kişi sayısı dünya genelinde 5.000.000'dur. Netflix'in diğer dijital medya platformlarından en önemli fark1 dizilerin yayınlanışını haftalara yaymayıp, tüm sezonu aynı anda yayınlamasıdır. Netflix ana markasının ikinci ürün hattını sinema filmleri oluşturmaktadır. Netflix medya merkezine göre Netflix son yıllarda insanları sinema salonlarına götürmeden evinde en az sinemada gösterilen filmler kadar kaliteli filmler göstermek istemektedir. Netflix ana markasının üçüncü ürün hattını Netflix belgeselleri oluştururken, dördüncü ürün hattını ise çocuklara yönelik animasyonlar oluşturmaktadır. Netflix ana markası ayrıca kendi üretimi olmayan başka yapımları da kendi yayın platformunda yayınlamaktadır. Netflix'de yayınlanan Netflix dışı yapımlar Netflix ana markasının beşinci ürün hattı olarak değerlendirilmektedir (About Netflix, E.Tarihi: 16.02.2021). Netflix ana markasının başarısının en temel nedeni müşterilerini doğru olarak analiz etmesidir. Netflix ana markası büyük veriyi kullanarak müşterilerinin zevk ve tercihlerini anlamakta ve bu doğrultuda müşterilerinin hoşuna gidecek içerik önerileri sunmaktadır. Netflix ana markasının başarısındaki diğer başlıca nedenleri ise müşterilere ödeme kolaylıkları sunulması, televizyon, bilgisayar, tablet, cep telefonu vb. birçok iletişim aracından kolayca platforma erişimin sağlanıyor olması ve müşterilerin platform içeriklerini rahatça kontrol edebilme(durdurma, hızlandırma, yavaşlatma) gücüne sahip olması durumları oluşturmaktadır (Cristina, Matlas ve Manuel, 2020, s. 262).

Netflix dijital medya platformu markasının sunduğu içeriklerin her biri Netflix markasının alt markaları olarak değerlendirilmekte ve platformun başarısında önemli bir yere sahip olmaktadır. 2014 yllinda içlerinde House of Cards, Hemlock Grove, Arrested Development ve Orange Is The New Black vb. pek çok yapımıla Netflix 31 dalda Emmy ödülüne aday gösterilmiş ve bu adaylıklarından dört tanesini kazanmıştır. 2016 yılına kadar olan süreçte Stranger Things, Beast of No Nation vb. yapımlarının başarısı sayesinde Netflix 190 ülkede erişime açılmış ve 50 milyon abone sayısına ulaşmıştır. Netflix, 2017 yılında The White Elmes belgeseliyle en iyi k1sa belgesel dalında, 2018 yllında ise Icarus belgeseliyle en iyi belgesel dalında Oscar ödülü kazanmayı başarmıştır. Netflix yapımları 2018 yılında 112 dalda Emmy ödülüne aday gösterilerek tarihte kırılması zor bir rekora sahip olmuşlardır. Netflix'in The Kissing Booth, Set It up, Sierra Burgess Is A Loser, Nappily ever After filmleri tüm zamanların en başarılı filmleri arasında değerlendirilmektedir (Netflix Company Analysis, 2019, s. 5).

\section{Yöntem}

Netflix dijital medya platformu ana markası ve Netflix dijital platformunda yer alan alt_markalar arasındaki marka mimarisi ilişkilerinin tespit edilmesini amaçlayan araştırmada bu amacı gerçekleştirmeye yönelik olarak medyan değerleri hesaplanmıştır. Medyan değerlerinin hesaplanmasındaki temel amaç verilerin doğru bir şekilde gruplanmasını sağlamaktır. Araştırmada ayrıca cinsiyet değişkeni için ana marka ve alt markalar arasındaki farklılıkların incelenmesi amacıyla T-testi yapılmıştır. T-testi iki ana kütle arasındaki farklılık düzeyini belirlemek için kullanılmaktadır (Karagöz, 2017, s. 188).

\section{Araştırmanın Hipotezleri}

Literatür incelendiğinde İşletmelerin ana marka isimlerinin tüketiciyi işletmeye çekmekte son derece etkili olduğu sonucuna varılmıştır. Örneğin Olins (1989, s. 82) çalışmasında Shell ve British Airways markalarının pazarlama faaliyetlerini kurumsal isimlerini vurgulayarak gerçekleştirmesinin markanın başarısında etkili olduğu sonucuna ulaşmışlardır. Yine Laforet ve Saunders (1994, s. 70) çalışmalarında Kellogs markasının ürünlerinde kendi kurumsal firma ismini ön plana çıkarmasının markanın pazarlama faaliyetlerindeki başarısını olumlu etkilediği sonucunu belirlemişlerdir. Ana markaların marka mimarisi özelliklerinin incelendiği birçok farklı alanda çalşsma olmasına karşın dijital medya platformu markalarına yönelik çalışma olmaması yazında boşluk oluşturmaktadır. Bu doğrultuda en önemli dijital medya platformu markalarından biri olan Netflix ana markasının marka mimarisi özelliklerini incelemek için aşağıdaki ana hipotez geliştirilmiştir: 


\section{H1: Netflix markasinn tercib edilmesinde bu markann mimari özellikleri daha etkilidir.}

Cezbedicilik özelliği markaların tüketiciyi çekmekte ne kadar etkili olduğuyla ilgilidir. Birçok farklı sektörde yapılan çalşma ana markaların cezbedicilik özelliğinin tüketiciyi markaya çekmekte etkili olduğu sonucunu saptamıştır. Örneğin; Muzellec ve Lambkin (2009, s. 48) çalışmalarında Unilever ve P\&G markalarının kurumsal isimlerinin tüketiciyi cezbederek ana markaya çektiği sonucuna ulaşmıştır. Benzer şekilde Rahman ve Arani (2013, s. 8) çalısmalarında spor giyim markalarının kurumsal isimlerinin cezbedicilik özelliği sayesinde tüketicilerde güven ve dürüstlük alg1sı yarattığını belirlemiştir. Ana markaların cezbedicilik özelliğine dayalı olarak oluşturdukları marka mimarisini içeren birçok farklı alanda çalışma olmasına karşın dijital medya platformu markalarına yönelik çalışma eksikliği yazında boşluk oluşturmaktadır. En önemli dijital medya platformu markalarından biri olan Netflix ana markasının marka mimarisinde cezbedicilik özelliğinin etkisini incelemek için aşağıdaki alt hipotez geliştirilmiştir.

\section{H1a: Netflix markasinn tercib edilmesinde bu markann cezbedicilik öz̨elliğ daha etkilidir.}

Merkezilik özelliği markaların tüketicinin gözündeki önemiyle ilgilidir. Keller'e göre (2008, s. 270) PepsiCo ana markası merkezilik özelliğinden dolayı tüketicinin gözünde önemli bir yere sahip olmaktadır. Yine Muylle, Dawar ve Rangarajan (2002, s. 67) çalısmalarında endüstriyel tekstil markası Milliken'in kurumsal ismi sayesinde müşterilerinin gözünde önemli bir yere sahip olmayı başardığını ifade etmiştir. Marka mimarisinin merkezilik özelliğine dayalı olarak dijital medya platformu ana markalarına yönelik çalışma olmaması yazında önemli bir eksikliktir. En önemli dijital medya platformu markalarından biri olan Netflix ana markasının marka mimarisinde merkezilik özelliğinin etkisini incelemek için aşağıdaki alt hipotez geliştirilmiştir.

\section{H1b: Netflix markasmm tercib edilmesinde bu markanm merkęilik. özelliği daha etkilidir.}

Kendini ifade özelliği markaların tüketiciyi ne kadar iyi yansıttı̆̆ıla ilgilidir. Tüketiciler kendini yansıtan markaları daha kolay bir şekilde tercih edebilmektedir. Şehir markalarına yönelik yapılan bir çalışmada, Barcelona şehrinin kültürel özellikler, doğal güzellikler ve mimari yapısıyla tüketicilerin bazı değerlerini yansıttığ için pazarlamacıların şehir pazarlaması faaliyetlerinde Barcelona marka ismini kullandığı sonucu ortaya çıkmıştır (Masip ve Poluzzi, 2014, s. 54). Hasanbegovic (2011, s. 41) çalışmasında P\&G'nin çevre dostu üretim, ambalajlama, dağitım teknikleri kullanarak kendisini çevre dostu marka olarak yansıttığı için kendi kurumsal isminin tüketiciler tarafindan benimsendiği sonucunu saptamıştır. Kendini ifade özelliğini içeren marka mimarisiyle ilgili pek çok farklı alanda çalışma olmasına rağmen dijital medya platformu ana markalarına yönelik yazında çalışma eksikliği bulunmaktadır. En önemli dijital medya platformu markalarından biri olan Netflix ana markasının marka mimarisinde kendini ifade özelliğinin etkisini incelemek için aşağıdaki alt hipotez geliştirilmiştir.

\section{H1c: Netflix markasmm tercih edilmesinde bu markann kendini ifade etme özelliği daha etkilidir.}

İşletmeler tüketicilerin algısını etkilemek için alt markaları kullanabilmektedir. Lagasse vd. (2018, s. 7) çalışmalarında Malboro sigara markasının bir alt markasının reklam stratejilerini ve ambalaj tasarımını tamamen ergen tüketicileri etkilemeye yönelik yapmasının firmanın ana markanın ulaşamadığı daha genç kitleyle bağlantı kurmasını sağladığını belirlemişlerdir. Jyrama vd. (2015, s. 204) çalışmalarında alt markaların güçlü olmasının ana markayı da güçlü hale getirdiğini ifade etmişlerdir. Alt markaların marka mimarisi özelliklerinin incelendiği birçok farklı alanda çalısma olmasına karşın dijital medya platformu markalarına yönelik çalışma olmaması yazında boşluk oluşturmaktadır. Bu doğrultuda en önemli dijital medya platformu markalarından biri olan Netflix'in alt markalarının marka mimarisi özelliklerini incelemek aşağıdaki ana hipotez geliştirilmiştir:

\section{H2: Netflix dizilerinin tercih edilmesinde bu markann mimari özellikleri daha etkilidir.}

Cezbedicilik özelliği tüketicileri alt markalara çekmekte etkili olmaktadır. Freire (2016, s. 70) turizm markaları çalışmasında Paris ana markasına ait Versay Sarayı alt markasının tüketicileri cezbettiği için Paris şehrine olan ilginin arttığı sonucuna ulaşmıştır. Benzer şekilde sigara markaları inceleyen bir çalışmada Malboro Fresh, Malboro Black Mentol vb. alt markaların cezbedici özellikleriyle tüketiciyi kendine çektiği sonucuna ulaşılmıștır (Dewhirst, 2018). Yazında alt markaların cezbedicilik özelliğine dayalı olarak oluşturdukları marka mimarisine dayalı birçok farklı alanda çalışma olmasına karşın dijital medya platformu markalarına yönelik çalışma eksikliği yazında boşluk olușturmaktadır. En önemli dijital medya platformu markalarından biri olan Netflix alt markalarının marka mimarisinde cezbedicilik özelliğinin etkisini incelemek için aşağıdaki alt hipotez geliştirilmiştir. 
H2a: Netflix dizilerinin tercih edilmesinde dizi markalarmm cez̧bedicilik özelliği daha etkilidir.

Merkezilik özelliği tüketici tercihleri üzerinde etkili olmaktadır. Spry, Foster ve Peart (2018, s. 348) üniversitelerin marka mimarilerini inceleyen çalışmasında alt marka olan fakültelerin üniversitenin genel eğitim kalitesininde belirleyici olduğu için tüketiciler tarafindan daha önemli görüldüğü sonucu saptanmıştır. Mensah (2016, s. 40) tarafından politika alanında yapılan marka mimarisi çalışmasında siyasi parti markalarının alt markaları olan adayların tüketiciler tarafından merkezi bir rolde olduğunun düşünüldüğü belirlenmiştir. Marka mimarisinin merkezilik özelliğine dayalı olarak dijital medya platformu alt markalarına yönelik çalışma olmaması yazında önemli bir eksikliktir. En önemli dijital medya platformu markalarından biri olan Netflix alt markalarının marka mimarisinde merkezilik özelliğinin etkisini incelemek için aşağıdaki alt hipotez geliştirilmiştir.

\section{H2b: Netflix dizilerinin tercih edilmesinde diẓi markalarmm merkęilik öz̨lliği daha etkilidir.}

Tüketiciler tıpkı ana markalar için olduğu gibi kendini ifade edebildikleri alt markalara da daha fazla yönelebilmektedir. Örneğin, Coca Cola Light ve Coco Cola Zero alt markalarını kullanan tüketiciler, daha çok sağlıklı ve zayıf görünme ihtiyaçlarını yansıttığı için bu markaları kullanmaktadır (Douglas ve Craig, 2001, s. 99). Örneğin, Apple Watch alt markasını kullanan tüketiciler daha çok kendisini yaratıcı olarak niteleyen kişilerden oluşmaktadır (Uglla, 2017, s. 8). Kendini ifade özelliğini içeren marka mimarisiyle ilgili pek çok farklı alanda çalışma olmasına rağmen dijital medya platformu alt markalarına yönelik yazında çalışma eksikliği bulunmaktadır. En önemli dijital medya platformu markalarından biri olan Netflix alt markalarının marka mimarisinde kendini ifade özelliğinin etkisini incelemek için aşağıdaki alt hipotez geliştirilmiştir.

\section{H2c: Netflix dizilerinin tercih edilmesinde dizi markalarmm kendini ifade etme özelliği daha etkilidir.}

Yazında cinsiyet ve marka ilişkisini inceleyen birçok çalışma bulunmaktadır. Lieven ve arkadaşları (2015, s. 153) marka isimlerinin anlamına verilen önemin cinsiyete göre farklılığını araştırdıkları çalışmalarında kadınların marka isimlerinin anlamlarına erkeklere göre daha fazla önem verdiği sonucunu saptamışlardır. Friedmann ve Lowengart (2018, s. 409) marka tercihlerinin cinsiyete göre farklilık nedenlerini araştırdığı çalışmasında erkeklerin marka tercihinde etkili olan en önemli faktörün ürün özellikleri olduğunu belirlerken kadınların ise marka tercihinde etkili olan faktörün markanın verdiği duygusal mesajlar olduğunu belirlemiştir. Klink (2009, s. 323) çalışmasında kadınların erkelere göre daha kolay telaffuz edilebilen markaları daha kolay algıladığını tesbit etmiştir. Lieven ve Hildebrand (2015, s. 181) çalışmalarında hem kadınların hem de erkeklerin kendi kişiliklerini yansıtan markalardan daha fazla alışveriş yaptığı sonucuna ulaşmıştır.

Cinsiyet ve marka arasındaki ilişkiyi inceleyen pek çok çalışma olmasına karşın marka mimarisi özelliklerinin cinsiyete göre farklılı̆ını inceleyen çalışma olmaması yazında önemli bir boşluk oluşturmaktadır. En önemli dijital medya platformu markalarından biri olan Netflix ana markasının ve alt markalarının marka mimarisi özelliklerinin cinsiyete göre farklılı̆̆ını belirlemek için aşağıdaki hipotezler önerilmektedir:

H3: Netflix ana markasinm tercih edilmesinde cezbedicilik özelliğ farkli cinsiyette olan izleyiciler arasinda farklulı göstermektedir.

H4: Netflix ana markasının tercih edilmesinde merkęilik özelligi farkli cinsiyette olan izleyiciler arasinda farklulı göstermektedir.

H5: Netflix ana markasmm tercih edilmesinde kendini ifade etme özelliği farkh cinsiyette olan izleyiciler arasinda farklulık göstermektedir.

H6: Netflix alt markalarmm tercih edilmesinde cez̧bedicilik öz̧elliüi farkl cinsiyette olan izleyiciler arasinda farklulı göstermektedir.

H7: Netflix alt markalarmm tercih edilmesinde merkezilik özelliği farkel cinsiyette olan izleyiciler arasinda farklulık göstermektedir.

H8: Netflix alt markalarmm tercih edilmesinde kendini ifade etme özelliği farkle cinsiyette olan izleyiciler arasinda farklulik göstermektedir. 


\section{Ana Kütle ve Örneklem Seçimi}

Dünya'da ve Türkiye'de oldukça tanınan bir dijital yayın platformu medya markası olan Netflix örneği üzerinden medya markalarının marka mimarisi stratejilerini tüketici üzerindeki etkisini belirlenmesinin amaçlandığı bu araştırmada kolayda örneklem yöntemiyle seçilen 300 tüketiciden anket yoluyla veriler toplanmıştır. Araştırma konusu olan Netflix markasının tercih edilme nedeni işletmenin kendisi tarafından üretilen ve dünya çapında bilinen çok fazla alt markaya sahip olmasıdır. Buna karşın Türkiye'deki diğer dijital yayın platformu markaları henüz yeterince alt markaya sahip olmadıkları için araştırma kapsamında incelenmeye uygun görülmemiştir.

\section{Veri Toplama Araçları}

Araştırma verilerinin elde edilmesinde kullanılan ölçek Kyle ve Women (2005, s. 350) tarafindan hazırlanmıştır. Bahsedilen ölçek tüketici verileri toplamaya uygun olup, daha önce marka mimarisiyle farklı alandaki çalıșmalarda da kullanılmıștır. Bahsedilen ölçek marka mimarisi modelinin uygunluğunu üç boyutu esas alarak değerlendirmektedir. Bu boyutlar cezbedicilik, merkezilik ve kendini ifade olmaktadır. Araştırma çerçevesindeki hem ana marka hem de alt markalar için sözü edilen boyutlar 22 ifade ile ölçülmüştür. Cezbedicilik (ana marka) 4 ifade, merkezilik (ana marka) 4 ifade, kendini ifade (ana marka) 3 ifade, cezbedicilik (alt marka) 4 ifade, merkezilik (alt marka) 4 ifade, kendini ifade (alt marka) 3 ifade ile ölçülmüştür. Ankette ayrıca cinsiyet, yaş, meslek grubu ve gelir durumundan oluşan tüketicilerin demografik bilgilerine ilişkin sorular da yer almaktadır. 5'li Likert tipi ölçeğine uygun olarak hazırlanan sorular tüketicilere online anket gönderilerek doldurtulmuştur.

\section{Verilerin Analizi}

Çalışmada öncelikli olarak kullanılan ölçeğin geçerlilik ve güvenilirlik analizi yapılmıştır. Daha sonra ana marka ve alt markalara ilişkin medyan değerleri belirlenerek ana marka ve alt markalar arasındaki iliş̧ilerin düzeyi tespit edilmiştir. Son olarak ise cinsiyet ve meslek grubu değişkenleri için ana marka ve alt markalar arasındaki farklılıkların incelenmesi amacıyla T-testi yapılmışır.

\section{Bulgular}

\section{Geçerlilik ve Güvenilirlik Analizleri}

Aşağıdaki Tablo 1 ölçekleri, ifadeleri, aritmetik ortalamalarını ve standart sapmalarını göstermektedir.

Tablo 1. Ölgekler, ifadeleri, Aritmetik Ortalamalar ve Standart Sapmalar

\begin{tabular}{|c|c|c|c|c|}
\hline ÖLÇEK & & MADDELER & Ortalama & SS \\
\hline \multirow{4}{*}{$\begin{array}{l}\text { Cezbedicil } \\
\text { ik (Netflix } \\
\text { Ana } \\
\text { Marka) }\end{array}$} & CezN1 & Dijital medya platformu markası benim için oldukça önemlidir. & 059 & 1,022 \\
\hline & CezN2 & $\begin{array}{l}\text { S1kıntılı olduğum zamanlarda dijital medya platformu markasını izlemek rahatlamamı } \\
\text { sağlamaktadır. }\end{array}$ & 061 & 1,050 \\
\hline & CezN3 & Dijital medya platformu markasını izlemek yaptığım en tatmin edici şeylerden birisidir. & 067 & 1,160 \\
\hline & CezN4 & Dijital medya platformu markasını izlemek gerçekten hoşuma gitmektedir. & 051 & 0,882 \\
\hline \multirow{4}{*}{$\begin{array}{l}\text { Merkezilik } \\
\text { (Netflix } \\
\text { Ana } \\
\text { Marka) }\end{array}$} & MerN1 & Dijital medya platformu markasını izlemek hayatımın çoğunu düzene sokmaktadır. & 061 & 1,049 \\
\hline & MerN2 & Dijital medya platformu markasının benim hayatımda temel bir rolü bulunmaktadır. & 064 & 1,112 \\
\hline & MerN3 & Dijital medya platformu markasını arkadaşlarımla tartışmaktan hoşlanırım. & 072 & 1,246 \\
\hline & MerN4 & $\begin{array}{l}\text { Dijital medya platformu markasını izlemekle hayatımın çoğu zamanı daha düzenli hale } \\
\text { geldi. }\end{array}$ & 061 & 1,065 \\
\hline \multirow{3}{*}{$\begin{array}{l}\text { Kendini } \\
\text { İfade } \\
\text { (Netflix } \\
\text { Ana } \\
\text { Marka) }\end{array}$} & KenN1 & Dijital medya platformu markasını izlemek kim olduğum hakkında çok şey söylemektedir. & ,068 & 1,186 \\
\hline & KenN2 & Dijital medya platformu izleyicisi hakkında çıkarımlarda bulunabilirim & 062 & 1,077 \\
\hline & KenN3 & Dijital medya platformu markasını izleyerek gerçekten kendim olabilirim. & 067 & 1,152 \\
\hline \multirow{4}{*}{$\begin{array}{l}\text { Cezbedicil } \\
\text { ik (Netflix } \\
\text { Dizileri- } \\
\text { Alt Marka) }\end{array}$} & CezD1 & Dijital medya platformu yapımları benim için oldukça önemlidir. & 063 & 1,084 \\
\hline & CezD2 & $\begin{array}{l}\text { Sıkıntılı olduğum zamanlarda dijital medya platformu yapımları izlemek rahatlamamı } \\
\text { sağlamaktadır. }\end{array}$ & 063 & 1,096 \\
\hline & CezD3 & Dijital medya platformu yapımlarını izlemek yaptığım en tatmin edici şeylerden birisidir. & 070 & 1,208 \\
\hline & CezD4 & Dijital medya platformu yapımlarını izlemek gerçekten hoşuma gitmektedir. & 054 & 0,943 \\
\hline \multirow{4}{*}{$\begin{array}{l}\text { Merkezilik } \\
\text { (Netflix } \\
\text { Dizileri- } \\
\text { Alt Marka) }\end{array}$} & MerD1 & Dijital medya platformu yapımlarını izlemek hayatımın çoğunu düzene sokmaktadır. & 065 & 1,123 \\
\hline & MerD2 & Dijital medya platformu yapımlarının benim hayatımda temel bir rolü bulunmaktadır. & 067 & 1,163 \\
\hline & MerD3 & Dijital medya platformu yapımlarını arkadaşlarımla tartışmaktan hoşlanırım. & ,067 & 1,162 \\
\hline & MerD4 & $\begin{array}{l}\text { Dijital medya platformu yapımlarını izlemekle hayatımın çoğu zamanı daha düzenli hale } \\
\text { geldi. }\end{array}$ & 062 & 1,078 \\
\hline \multirow{3}{*}{$\begin{array}{l}\text { Kendini } \\
\text { Iffade } \\
\text { (Netflix } \\
\text { Dizileri } \\
\text { Alt Marka) }\end{array}$} & KenD1 & $\begin{array}{l}\begin{array}{l}\text { Dijital medya platformu yapımlarını izlemek kim olduğum hakkında çok şey } \\
\text { söylemektedir. }\end{array}\end{array}$ &, 069 & 1,189 \\
\hline & $\begin{array}{l}\text { KendD } \\
2\end{array}$ & Dijital medya platformu yapımlarını izleyen bir insan hakkında çıkarımlarda bulunabilirim. & ,065 & 1,131 \\
\hline & KenD3 & Dijital medya platformu yapımlarını izleyerek gerçekten kendim olabilirim. & 071 & 1,223 \\
\hline
\end{tabular}


Araştırmada ana marka ve alt markalar için kullanılan Cezbedicilik (Netflix Ana Marka), Merkezilik (Netflix Ana Marka), Kendini İfade (Netflix Ana Marka), Cezbedicilik (Netflix Dizileri- Alt Marka), Merkezilik (Netflix Dizileri- Alt Marka), Kendini İfade (Netflix Dizileri Alt Marka) boyutlarına ilişkin güvenilirlik analizi yapılmıştır. Yapılan analiz sonucunda Cronbach's Alpha oranlarının her bir ölçek için uygun seviyede olduğu anlaşıldığı için verilerin güvenilir olduğu sonucuna varılmıştır. Araştırmada yer alan unsurların ölçeğe uygunluğunun belirlenmesi için yapılan keşfedici faktör analizi neticesinde KMO (Kaiser-Meyer-Olkin) değerlerinin Cezbedicilik (Netflix Ana Marka): 0,757; Merkezilik (Netflix Ana Marka): 0, 773; Kendini İfade (Netflix Ana Marka): 0,680; Cezbedicilik (Netflix Dizileri- Alt Marka): 0,789; Merkezilik (Netflix Dizileri- Alt Marka): 0,760; Kendini İfade (Netflix Dizileri Alt Marka): 0, 701 olduğu saptanmıştır. Her değişken için Kaiser-Meyer-Olkin değerlerinin 0,50 sınırının altında olmadığı ve Bartlet küresellik testinin de her değişken için anlamlı olduğu $(\mathrm{P}=0.000)$ sonucuna varılmışır. Yapılan analiz sonucunda her değişkenin tek faktörlü bir yapı içerisinde yer aldığı ve ölçek maddelerinin faktör yüklerinin 0,05 in üzerinde olduğu için geçerli sayıldığı anlaşılmıştır. Ölçek maddelerinin faktör yükleri ve Cronbach's Alpha oranları (güvenilirlik) aşağıdaki tabloda gösterilmiştir.

Tablo 2. Güvenilirlik ve Geçerlilik Testi Sonuclar

\begin{tabular}{|c|c|c|c|c|}
\hline Ölçekler & Ölçek Maddeleri & Faktör Yükleri & Açıklanan Varyans & Cronbach Alpha \\
\hline \multirow{4}{*}{$\begin{array}{l}\text { Cezbedicilik (Netflix } \\
\text { Ana Marka) }\end{array}$} & CezN1 & 0,690 & 63,619 & 0,804 \\
\hline & CezN2 & 0,836 & & \\
\hline & CezN3 & 0,833 & & \\
\hline & CezN4 & 0,822 & & \\
\hline \multirow{4}{*}{$\begin{array}{l}\text { Merkezilik (Netflix } \\
\text { Ana Marka) }\end{array}$} & MerN1 & 0,818 & 64,045 & 0,799 \\
\hline & MerN2 & 0,850 & & \\
\hline & MerN3 & 0,623 & & \\
\hline & MerN4 & 0,884 & & \\
\hline \multirow{3}{*}{$\begin{array}{l}\text { Kendini İfade (Netflix } \\
\text { Ana Marka) }\end{array}$} & KenN1 & 0,852 & 66,910 & 0,752 \\
\hline & KenN2 & 0,797 & & \\
\hline & KenN3 & 0,804 & & \\
\hline \multirow{4}{*}{$\begin{array}{l}\text { Cezbedicilik (Netflix } \\
\text { Dizileri- Alt Marka) }\end{array}$} & CezD1 & 0,811 & 66,546 & 0,830 \\
\hline & CezD2 & 0,826 & & \\
\hline & CezD3 & 0,828 & & \\
\hline & CezD4 & 0,797 & & \\
\hline \multirow{4}{*}{$\begin{array}{l}\text { Merkezilik (Netflix } \\
\text { Dizileri- Alt Marka) }\end{array}$} & MerD1 & 0,879 & 66,055 & 0,816 \\
\hline & MerD2 & 0,848 & & \\
\hline & MerD3 & 0,579 & & \\
\hline & MerD4 & 0903 & & \\
\hline \multirow{3}{*}{$\begin{array}{l}\text { Kendini İfade (Netflix } \\
\text { Dizileri Alt Marka) }\end{array}$} & KenD1 & ,916 & 77,086 & 0,850 \\
\hline & KendD2 & 863 & & \\
\hline & KenD3 &, 854 & & \\
\hline
\end{tabular}

\section{Ana Marka ve Alt Marka Özelliklerinin Değerlendirilmesi}

$\mathrm{Bu}$ araştırmada izleyicilerin ana marka (Netflix) ve alt markaların (dizilerin) marka mimarisinin cezbedicilik, merkezicilik ve kendini ifade etme özelliklerine göre farklıllkları incelenmiştir. Ana marka ve alt markalarda izleyicilerin en çok önem verdikleri özelliğe bakılmıştır. Bu nedenle izleyicilerin her iki kategoride marka özelliklerinin seviyesine göre yüksek ve düşük verilerini gruplandırmak amacıyla her özellik için medyan değeri hesaplanmıştır. Netflix dizileri yazında da sözü edildiği gibi platformun dünya çapında tanınmasını sağlaması, pazarın genişletilmesini kolaylaştırması, platforma yeni müşteriler kazandırması özellikleri nedeniyle alt markalar olarak değerlendirilmektedir. Araştırma kapsamında alt markalar olarak Netflix Türkiye'de çok izlenen diziler olan Atiye, La Ceseda Papel, The Witcher, Hakan Muhafiz, Stranger Things, Black Mirror, Dark, The Umberalla Academy, The I-and ve You dizileri ele alınmıştır.

Ana marka (Netflix) kategorisinde medyan değeri markanın cezbedicilik özelliği için 3.50 olarak bulunmuştur. $\mathrm{Bu}$ şekilde bu değer üstünde olanlar yüksek cezbedicilik düzeyi $(\mathrm{N}=173)$ grubunu oluşturmuştur. Buna göre, katılımcıların 173’ü Netflix ana markasının yüksek cezbedicilik özelliğine sahip olduğunu kabul etmişlerdir. Bu nedenle H1a hipotezi kabul edilmiştir.

Ana marka (Netflix) kategorisinde medyan değeri markanın merkezilik özelliği için 2.50 olarak bulunmuştur. $\mathrm{Bu}$ şekilde bu değer üstünde olanlar yüksek merkezilik düzeyi $(\mathrm{N}=190)$ grubunu oluşturmuştur. Buna göre, katılımcıların 190’1 Netflix ana markasının yüksek merkezilik özelliğine sahip olduğunu kabul etmişlerdir. Bu nedenle H1b hipotezi kabul edilmiştir. 
Ana marka (Netflix) kategorisinde medyan değeri markanın kendini ifade özelliği için 3.00 olarak bulunmuştur. $\mathrm{Bu}$ şekilde bu değer üstünde olanlar yüksek kendini ifade düzeyi $(\mathrm{N}=155)$ grubunu oluşturmuştur. Buna göre, katılımcıların 155’i Netflix ana markasının yüksek kendini ifade özelliğine sahip olduğunu kabul etmişlerdir. Bu nedenle H1C hipotezi kabul edilmiştir.

Alt markalar yani diziler kategorisinde medyan değeri markaların cezbedicilik özelliği için 3.50 olarak bulunmuştur. $\mathrm{Bu}$ şekilde bu değer üstünde olanlar yüksek cezbedicilik düzeyi $(\mathrm{N}=163)$ grubunu oluşturmuştur. Buna göre, katılımcıların 163’ü dizilerin (alt markaların) yüksek cezbedicilik özelliğine sahip olduğunu kabul etmişlerdir. Bu nedenle $\mathrm{H} 2$ a hipotezi kabul edilmiştir.

Alt markalar yani diziler kategorisinde medyan değeri markaların merkezilik özelliği için 2.50 olarak bulunmuştur. $\mathrm{Bu}$ şekilde bu değer üstünde olanlar yüksek merkezilik düzeyi $(\mathrm{N}=184)$ grubunu oluşturmuştur. Buna göre, katılımcıların 184'ü dizilerin (alt markaların) yüksek merkezilik özelliğine sahip olduğunu kabul etmişlerdir. Bu nedenle H2b hipotezi kabul edilmiştir.

Alt markalar yani diziler kategorisinde medyan değeri markaların kendini ifade özelliği için 2.66 olarak bulunmuştur. $\mathrm{Bu}$ şekilde bu değer üstünde olanlar yüksek kendini ifade düzeyi $(\mathrm{N}=167)$ grubunu oluşturmuştur. Buna göre, katılımcıların 167'si dizilerin (alt markaların) yüksek kendini ifade özelliğine sahip olduğunu kabul etmişlerdir. Bu nedenle $\mathrm{H} 2 \mathrm{c}$ hipotezi kabul edilmiştir.

Tablo 3. Hipotę Testleri Özeti

\begin{tabular}{llll}
\hline & Değişkenler & Hipotez & Kabul/Red \\
\hline Netflix Ana Marka & Marka Mimarisi Özellikleri & H1 & KABUL \\
\hline Netflix Ana Marka & Cezbedicilik & H1a & KABUL \\
\hline Netflix Ana Marka & Merkezilik & H1b & KABUL \\
\hline Netflix Ana Marka & Kendini İfade & H1c & KABUL \\
\hline Netflix Alt Markaları (Diziler) & Marka Mimarisi Özellikleri & H2 & KABUL \\
\hline Netflix Alt Markaları (Diziler) & Cezbedicilik & H2a & KABUL \\
\hline Netflix Alt Markaları (Diziler) & Merkezilik & H2b & KABUL \\
\hline Netflix Alt Markaları (Diziler) & Kendini İfade & H2c & KABUL \\
\hline
\end{tabular}

Medyan değerlerinin hesaplanması sonucunda izleyicilerin gözünde marka mimarisinin cezbedicilik, merkezilik ve kendini ifade özelliklerinin hem ana marka (Netflix) ve hem de alt markalar (Netflix dizileri için önemli olduğu görülmüştür. Bu doğrultuda $\mathrm{H} 1$ ve $\mathrm{H} 2$ hipotezleri kabul edilmiştir. Medyan değerleri karşılaştırıldığında Netflix ana markasının cezbedicilik düzeyinin (N=173) Netflix alt markalarının cezbedicilik düzeyine $(\mathrm{N}=163)$ göre daha yüksek ve Netflix ana markasının merkezilik düzeyinin $(\mathrm{N}=190)$ Netflix alt markalarının merkezilik düzeyine $(\mathrm{M}=184)$ göre daha yüksek olduğu sonuçlarına ulaşılmıştır. Netflix alt markalarının kendini ifade düzeyinin ise ( $\mathrm{N}=167)$ Netflix ana markasının kendini ifade düzeyine ( $N=155)$ göre daha fazla olduğu anlaşılmıştır.

\section{İzleyicilerin Cinsiyeti İle Marka Mimarisi Bileşenlerine İlişkin Sonuçlar}

Bu araştırmada ayrıca ana marka (Netflix) ve alt markaların (dizilerin) cezbedicilik, merkezicilik ve kendini ifade etme özelliklerinin izleyicilerin cinsiyet değişkenine ilişkin farklılıklarını açıklamak hedeflenmektedir. Cinsiyet (Erkek-Kadın) değişkeni iki bağımsız gruptan oluştuğu için fark analizinin yapılmasında t-testi kullanılmıştır.

Araştırma modelindeki değişkenlerde, anketi cevaplayanların cinsiyetlerine göre farklılık olup olmadığ1 t testi ile analiz edilmiştir. Toplamda 300 kişi olan örneklemde 186 kadın, 114 erkek yer almaktadır. Araştırmadaki değişkenlerle yapılan t-Testi aşağıdaki Tablo 3 'te gösterilmektedir.

Tablo 4. Cinsiyet Değişkeninin t-Testi Sonuglarn

\begin{tabular}{|c|c|c|c|c|c|}
\hline Değişkenler & Cinsiyet & $\mathbf{N}$ & Ortalama & Std.Sapma & p Değeri \\
\hline \multirow{2}{*}{$\begin{array}{l}\text { Cezbedicilik /Ana } \\
\text { Marka / (Netflix) }\end{array}$} & Kadin & 186 & 3,4866 & 0,79472 & \multirow[t]{2}{*}{0,250} \\
\hline & Erkek & 114 & 3,3289 & 0,85401 & \\
\hline \multirow{2}{*}{$\begin{array}{l}\text { Merkezilik/ Ana } \\
\text { Marka/ (Netflix) }\end{array}$} & Kadın & 186 & 2,7446 & 0,82608 & \multirow[t]{2}{*}{0,038} \\
\hline & Erkek & 114 & 2,7193 & 0,97657 & \\
\hline \multirow{2}{*}{$\begin{array}{l}\text { Kendini İfade/ Ana } \\
\text { Marka/ (Netflix) }\end{array}$} & Kadin & 186 & 2,8226 & 0,90189 & \multirow[t]{2}{*}{0,420} \\
\hline & Erkek & 114 & 2,8099 & 0,98261 & \\
\hline \multirow{2}{*}{$\begin{array}{l}\text { Cezbedicilik/ Alt } \\
\text { Marka/ (Diziler) }\end{array}$} & Kadin & 186 & 3,3831 & 0,87462 & \multirow[t]{2}{*}{0,596} \\
\hline & Erkek & 114 & 3,2149 & 0,89485 & \\
\hline \multirow{2}{*}{$\begin{array}{l}\text { Merkezilik / Alt } \\
\text { Marka/ (Diziler) }\end{array}$} & Kadın & 186 & 2,6962 & 0,87406 & \multirow[t]{2}{*}{0,266} \\
\hline & Erkek & 114 & 2,7171 & 0,96654 & \\
\hline \multirow{2}{*}{$\begin{array}{l}\text { Kendini İfade/ Alt } \\
\text { Marka/ (Diziler) }\end{array}$} & Kadın & 186 & 2,7043 & 1,01242 & \multirow[t]{2}{*}{0,674} \\
\hline & Erkek & 114 & 2,8246 & 1,07461 & \\
\hline
\end{tabular}


Katılımcıların, araştırma çerçevesindeki değişkenlere vermiş oldukları cevapların karşılaştırılması için yapılmış olan $\mathrm{t}$ testi sonrasında cezbededicilik (ana marka), kendini ifade (ana marka), cezbedicilik (alt marka), merkezilik (alt marka) ve kendini ifade (alt marka) için cinsiyet türüne göre anlamlı bir farklılık görülmemektedir. ( $p>0,05)$. Merkezilik (ana marka) için ise, kadınların erkeklere göre ana markadan daha fazla etkilediği görülmektedir ( $\mathrm{p}<0,05)$ (MKadın=2,74, MErkek=2,71). Bu doğrultuda H4 hipotezi kabul görürken $\mathrm{H} 3, \mathrm{H} 5, \mathrm{H} 6, \mathrm{H} 7, \mathrm{H} 8$ hipotezleri reddedilmiştir.

Tablo 5. Cinsiyet Değişkeninin Hipotez Testleri Özeti

\begin{tabular}{|c|c|c|c|}
\hline & Değgişkenler & Hipotez & Kabul/Red \\
\hline Netflix Ana Marka & Cezbedicilik & H3 & Red \\
\hline Netflix Ana Marka & Merkezilik & $\mathrm{H} 4$ & Kabul \\
\hline Netflix Ana Marka & Kendini Iffade & H5 & Red \\
\hline Netflix Alt Markaları (Diziler) & Cezbedicilik & H6 & Red \\
\hline Netflix Alt Markaları (Diziler) & Merkezilik & $\mathrm{H} 7$ & Red \\
\hline Netflix Alt Markaları (Diziler) & Kendini İfade & $\mathrm{H} 8$ & Red \\
\hline
\end{tabular}

\section{Sonuç ve Öneriler}

Dijital medya platformlarının izleyici sayısı hızlı bir şekilde artmaktadır. Dijital medya platformu markaları ürettikleri içeriklerle televizyon medyasına çok ciddi bir rakip durumuna gelmiştir. Artan ilgi son dönemlerde giderek daha fazla dijital medya platformu markasının ortaya çıkmasına neden olmuştur. Bugün Netflix, HBO Max, Apple Tv, Disney Plus vb. küresel anlamlarda rekabet eden çok ciddi dijital medya platformu markaları bulunmaktadır.

Bununla birlikte dijital medya platformu markaları çok sayıda dizi, film, belgesel vb. alt markalar üreterek dünya genelinde daha fazla tüketiciye ulaşmayı amaçlamaktadır. Bugüne kadar pek çok farklı sektörün marka mimarisini nasıl şekillendirdiğine yönelik çalışmalar yapılmış olsa da, yazında dijital medya platformu markalarının marka mimarisine yönelik bir çalışmaya rastlanmamışırı. Bu araştırma yazındaki bu eksikliği gidermek amacıyla dünyanın en çok abone sayısına sahip markası olan Netflix'in marka mimarisini incelemiştir.

Bu çalışmanın amacı, Netflix ana markası ve Netflix’te yayınlanan diziler yani alt markaları arasında marka mimarisi özellikleri açısından farklılıkları ortaya çıkarmaktır. Araştırmada Netflix ana markası ve ana markaya bağlı alt markaların arasında üç marka mimarisi özelliğine (cezbedicilik, merkezilik ve kendini ifade) bağlı olarak farklılıkların nasıl ortaya çıtı̆̆ı tespit edilmiştir. Ayrıca araştırma çerçevesinde marka mimarisinin cinsiyet (kadın-erkek) ve meslek grubu (öğrenciler-diğer) değişkenleri için farklilık oluşturup oluşturmadığ $1 \mathrm{da}$ incelenmiştir. Araştırmadaki ilişkileri incelemek amacıyla 300 Netflix izleyicisinden veri toplanmış ve anket sonuçları SPSS v. 24 programında analiz edilmiştir.

Yapılan analiz sonucunda medyan değerleri incelendiğinde hem Netflix ana markasının hem de Netflix alt markalarının üç marka mimarisi özelliğinden etkilendiği sonucuna ulaşılmıştır. Bu sonuçlardan hareketle hem Netflix ana markasının hem de alt markalarının izleyicilere cazip geldiği, onların hayatında önemli bir yeri olduğu ve izleyicilerin hayat tarzını yansıttığı sonucuna ulaşılmıştır.

Yapılan analiz sonucunda merkezilik (ana marka) özelliğinin kadınlar üzerinde daha fazla etkili olduğu sonucuna ulaşılmıştır. Bu sonuç, Netflix'in kadınların hayatında daha önemli bir yere sahip olduğu sonucunu göstermektedir.

$\mathrm{Bu}$ araştırma, Netflix markasının marka mimarisi özelliklerinin tüketiciyi nasıl etkilediğini ortaya koymuştur. Yine marka mimarisi özelliklerinin cinsiyet(kadın-erkek) göre farklılık gösterip gösterilmediği açıklığa kavuşturulmuştur. Bu araştırma Netflix dışındaki diğer medya platformlarının marka mimarisinin de incelenmesine ön ayak olarak ileride yapılacak diğer araştırmalara da 1şık tutacaktır.

\section{Etik Beyan}

"Medya Sektöründe Marka Mimarisi: Türkije Örneği." başlıklı çalışmanın yazım sürecinde bilimsel kurallara, etik ve alıntı kurallarına uyulmuş; toplanan veriler üzerinde herhangi bir tahrifat yapılmamış ve bu çalışma herhangi başka bir akademik yayın ortamına değerlendirme için gönderilmemiştir. Gerekli olan etik kurul izinleri İstanbul Gelişim Üniversitesi Etik Kurul Başkanlığının 04.11.2020 tarih ve 2020-27 sayll toplantısında alınmıştır. 


\section{Kaynakça}

About Netflix. Netflix Media Center, 17 Şubat 2021 tarihinde http://www.netflix.com/en/about-netflix. adresinden erişildi.

Aaker, D. A. ve Joachimsthaler, E. (2000). Brand leadership second edition. The Free Press.

Aaker, D.A. ve Joachimsthaler, E. (2000). The brand relationship spectrum: the key to the brand architecture challenge. Califorma Management Review, 42 (4), 8-23.

Beaton, A. A., Funk, D. C., Ridinger, L. ve Jordan, J. (2011). Sport involvement: A conceptual and empirical analysis. Sport management review, 14(2), 126-140.

Blair, T., Burrer, T., Garcia, J., Hernandez, A., Li-Southwick, Q. Y., Logar, K. ve Porter, L. (2019) Netflix Company Analysss (PDF Belgesi). 17 Şubat 2021 tarihinde http://tessacreates.com/wp-content/uploads/pdfs/NetflixCompanyAnalysis.pdf adresinden erişildi.

Dauglas, S., Craig, S. ve Edwin, N. (2001). Integrating branding strategy across markets: building international brand architecture. Journal of International Marketing, 9(2), 97-111.

Dewhirst, T. (2018). Into the black: Marlboro Brand Architecture, Packaging And Marketing Communication Of Relative Harm. Tobacca Control, 27(2), 240-242.

Dinnie, K. (2018) Contingent self-definition and amorphous regions: A dynamic approach to place brand architecture. Marketing Theory, 18(1), 31-53

Esbjberg, L. ve Larsen, T. B. (2009). The brand architecture of grocery retailers: Setting material and symbolic boundaries for consumer choice. Journal of Retailing and Consumer Services, 16(5), 414-423.

Freire J. (2016). Managing destination brand architecture - The case of Cascais Municipality. Place Branding and Public Diplomacy, 12(1), 78-90.

Friedmann, E. ve Lowengart, O. (2019). Gender segmentation to increase brand preference? The role of product involvement. Journal of Product \& Brand Management, 28(3), 408-420.

González-Chans, C., Membiela-Pollán, M. ve Cortés-Cuns, M. (2020). Relationship marketing and brand community: the case of Netflix. Revista de Marketing Aplicado, 24(2), 251-274.

Harish, R. (2008). Brand architecture and its application in strategic marketing: The example of L'Oréal. The Icfai University Journal of Brand Management, 6(2), 40-51.

Hasanbegovic, D. (2011). Corporate reputation and brand architecture: The debate. See Journal, 6(2), 37.43.

Horng, J. S., Liu, C. H., Chou, H. Y. ve Tsai, C. Y. (2012). Understanding the impact of culinary brand equity and destination familiarity on travel intentions. Tourism management, 33(4), 815-824.

Jyrama, A. S. Kajalo, Johannson, T ve Siren, A. (2015). Brand architecture, drivers of consumer involvement, and brand loyalty with professional sport leagues and teams. The Journal of Arts Management, Law, and Society, 27(3), 177-192.

Kanitz, C. ve Burmann, C. (2012). The challenge of pharmaceutical brand architecture: A theoretical analysis based on the Brand Architecture Model (BAM). The Marketing Review, 12(3), 309-326.

Kapferer, J.N. (2004). The new strategic brand management: Creating and sustaining brand equity long term (Second Edition). Kogan Page Publishers.

Karagöz, Y. (2017). SPSS ve AMOS uygulamal nitel-nicel-karma bilimsel araştırma yöntemleri ve yayın etiüz (1. Basım). Ankara: Nobel Akademik Yayıncilik.

Keller, K. L. (2008). Strategic brand management building, measuring, and managing brand equity (4 ${ }^{\text {th }}$ Edition). Pearson Inc.

Klink, R. R. (2009). Gender differences in new brand name response. Marketing Letters, 20(3), 313-326.

Krunert, K. G., Esbjerg L., Larsen T. B, Bruno, K. ve Juhl. H. J. (2006) Consumer preferences for retailer brand architectures: results from a conjoint study. International Journal of Retail \& Distribution Management, 34(8), $597-$ 608.

Kunkel, T., Funk, D. ve Hill, B. (2013). Brand architecture, drivers of consumer involvement, and brand loyalty with professional sport leagues and teams. Journal of Sport Management, 27(3), 177-192.

Laforet, S. ve Saunders, J. (2005). Managing Brand Portfolios: How Strategies Have Changed. Journal of Advertising Research. 45(3), 314-327.

Laforet, S. ve Saunders, J. (1994). Managing brand portfolios: how the leaders do it. Journal of Advertising Research, 34(5), 64-77.

Lagasse, L. P., Minosa, M. K. R., Moran, M. B., ve Cohen, J. E. (2018). “Decide now, buy Marlboro”: Examining the influence and appeal of Marlboro's new brand architecture among Filipino adolescents. International Journal of Adolescent Medicine and Health, 1, 24-42.

Lieven, T. ve Hildebrand, C. (2016). The impact of brand gender on brand equity. International Marketing Review, 33(2), 178-195.

Lieven, T., Grohmann, B., Herrmann, A., Landwehr, J. R. ve Van Tilburg, M. (2015). The effect of brand design on brand gender perceptions and brand preference. European Journal of Marketing, 1(1/2), 146-169.

Masip, J. D. ve Poluzzi, A. (2014). Brand architecture management: The case of four tourist destinations in Catalonia. Journal of Destination Marketing \& Management, 3(1), 48-58.

Mensah, K. (2016). Political brand architecture: Towards a new conceptualisation of political branding in an emerging democracy. African Journalism Studies, 37(3), 61-84.

Muyyle, S., Dawar N. ve Rangarajan D. (2012). B2B brand architecture. Calforma Management Review, 54(2), 58-71. 
Muzellec, L. ve Lambkin, M. (2009). Corporate branding and brand architecture: a conceptual framework. Marketing Theory, 9(39), 39-54.

Olins,W. (1989). Corporate identity: Making business strategy visible through design (Fourth Edition). London: Thames and Hudson.

Rahman, K. ve Areni C. (2014). Marketing strategies for services: is brand architecture a viable way Forward? Journal of Strategic Marketing, 22(4), 328-346.

Rahman, K. ve Areni, C. (2014). Generic, genuine, or completely new? Branding strategies to leverage new products. Journal of Strategic Management, 22(1), 3-15.

Rajagopal ve Sanchez, R. (2003). Conceptual analysis of brand architecture and relationships within product categories. Journal of Brand Management, 11(3), 233-247.

Rehman, A. ve Jamil, S. A. (2016). Influence of income and occupation on consumers' susceptibility to reference group demands on brand choice decisions. International Review of Management and Marketing, 6(2), 376-382.

Saunders, J. ve Guoqun, F. (1997). Dual branding: how corporate names add value. Journal of Product and Brand Management, 6(1), 40-48.

Simmons, C.J ve Bickart, B.A. (2000). Leveraging equity across the brand portfolio. Kluwer Academic Publishers, 11(3), 233-247.

Spry, L., Foster, C., Pich, C. ve Peart, S. (2020). Managing higher education brands with an emerging brand architecture: the role of shared values and competing brand identities. Journal of Strategic Marketing, 28(4), 336349.

Uggla, H. ve Philipson D. (2009). Ingredient Branding: Strategic Guidelines. The Indian Journal of Brand Management, $5(2), 16-30$

Uglla, H. (2017). Luxury Brand Architecture Challenges. IUP Journal of Brand Management, 14(1), 7-12.

Wang, Y. H. ve Tsai, C. F. (2014). The relationship between brand image and purchase intention: Evidence from award winning mutual funds. The international journal of business and finance research, 8(2), 27-40.

\section{EXTENDED ABSTRACT}

Enterprises create brands by using many components such as names, symbols, etc and gathering them to gether to identify the source of their products and to distinguish them from their competitors. The system that collocates the relationship between brand and product is called brand architecture (Kapfarer, 2004, p. 310). The expressions used in literature of the study as equivalent with the concept of brand architecture are brand hierarchy, brand portfolio and brand strategies. The concept of brand architecture is very important for marketers. Brand architecture guides marketers about existing and new products how to apply brand names, logos, symbols and other brand-related ingredients (Keller, 2014, p.703). Brands aim to link market opportunities, departments, and the features of the products they offer, to gether psychologically via brand architecture (Uglla, \& Philipsonn, 2009, p. 19). Brands are placed hierarchically within the brand system over brand architecture. In this way, common use is utilized via creating synergy, brand identity damage is reduced, clearer offers are given to customers about the brand and changing becomes easier. Each brand that is placed hierarchically in brand architecture has a specific role and these roles are associated with brands at other levels (Aaker, \& Joachimsthaler, 2000, p. 282).

Media brands are one of the most important areas where there is a lack of study about brand architecture. It doesn't found any brand architecture study intended media brands in the world and Turkey. It is anticipated that a brand architecture study conducting digital broadcasting platforms as media brands that emerged with development of the internet will constitute a reference for studies towards media brands in other fields. The purpose of this study is to reveal the differences in terms of brand architecture features between Netflix as main brand and the TV series broadcast on Netflix, as subbrands.

This study aimed to examine the impact of brand architecture strategies of Netflix, digital publishing platform media brand as recognized fairly in the world and Turkey, on consumers. The proposed hypotheses were tested using a survey based-study, with a sample size of 300 viewers. The results indicate that the reason of Netflix brand preference is that it has a lot of sub-brands produced by the business itself and are well-known around the world. However, other brands of digital broadcasting platform in Turkey don't have enough sub-brands yet, that's why they have not be approved to examine in scope of the research. The scale used to obtain data was prepared by Kyle and Women (2005, p. 350). The mentioned scale is suitable for collecting viewer's data and has been used in studies related to brand architecture in different fields. The mentioned scale evaluates the conformity of the brand architecture model based on three dimensions. These dimensions are attractiveness, centrality and self-expression. The dimensions mentioned for both the main brand and sub brands within the framework of the research 
were measured with 22 statements. Attractiveness (main brand) with 4 expressions, centrality (main brand) with 4 expressions, self-expression (main brand) with 3 expressions, attractiveness (sub brands) with 4 expressions, centrality (sub brands) with 4 expressions and self-expression (sub brands) with 3 expressions were measured. The questionnaire also encloses questions based on demographic information of the viewers, including gender, age, occupation, income and residence status. Consumers were randomly intercepted and recruited to attend in the study. The respondents assessed all items on five-point Likerttype scales ranging from 1 (strongly disagree) to 5 (strongly agree) via online questionnaire sent them.

In this study, it was determined how the differences between Netflix main brand and its sub-brands appear consistent with three brand architecture characteristics (attractiveness, centrality and selfexpression). In addition, it was examined the variables of brand architecture within the framework of the research, whether there is a difference between gender and occupation groups.

With respect to the results of analysis, it was stated that both Netflix main brand and Netflix sub brands were affected by three brand architecture features. Based on these results, it was concluded that both Netflix main brand and its sub-brands are attractive to viewers, have an important place in their lives and reflect the lifestyle of the viewers.

Concerning the result of the analysis, the centrality (main brand) feature is more effective on women. This result clarifies that Netflix (main brand) has a more important place in women's lives.

The results demonstrate that the attractiveness (main brand) feature was more effective on students. Thus, Netflix (the main brand) is more attractive for students than other professional groups.

This research has revealed how the brand architecture features of Netflix brand affect the viewers. It was indicated whether the characteristics of brand architecture differ by gender and occupational groups as well. This research will brighten other studies to declare the brand architecture of other media platforms. 